\title{
RHEUMATIC MITRAL STENOSIS AND AORTIC INCOMPETENCE IN A CASE OF DEXTROCARDIA WITH SITUS INVERSUS
}

BY

\author{
N. R. KONAR AND D. C. ROY CHAUDHURY
}

From the Nilratan Sircar Medical College, Calcutta

Dextrocardia with situs inversus is not common and rheumatic valvular lesions in such cases are rare (Table I). It is considered that the circumstances of the case now described are worthy of record.

TABLE I

Reported Cases of Rheumatic Heart Diseases in Dextrocardia with Situs Inversus

\begin{tabular}{|c|c|c|c|c|}
\hline Author & Age & Sex & $\begin{array}{l}\text { Age at first } \\
\text { rheumatic } \\
\text { attack } \\
\text { (years) }\end{array}$ & $\begin{array}{c}\text { Type of valvular } \\
\text { lesion }\end{array}$ \\
\hline 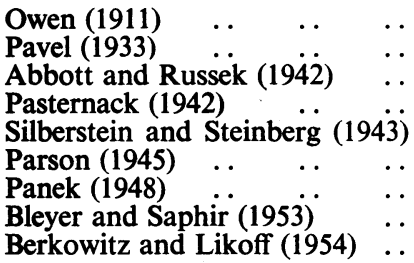 & $\begin{array}{l}29 \\
43 \\
\\
33 \\
24 \\
45 \\
36 \\
32\end{array}$ & $\begin{array}{l}\mathbf{M} \\
\mathbf{M} \\
\mathrm{F} \\
\mathrm{F} \\
\mathrm{F} \\
\mathrm{F} \\
\mathrm{F}\end{array}$ & $\begin{array}{r}7 \\
? \\
13 \\
21 \\
9 \\
18 \\
-\end{array}$ & $\begin{array}{l}\text { Mitral stenosis } \\
\text { Aortic incompetence } \\
\text { Aortic stenosis } \\
\text { Mitral incompetence and stenosis } \\
\text { Combined aortic and mitral lesion } \\
\text { Mitral incompetence and stenosis } \\
\text { Mitral incompetence and stenosis } \\
\text { Mitral stenosis }\end{array}$ \\
\hline
\end{tabular}

\section{Case History}

A married girl, aged 14 years, was admitted to Nilratan Sircar Medical College Hospital with the history of continued fever for eight days. She had previously suffered from continued fever for about a month and was afebrile for a fortnight before she had this relapse. The patient had no cardiac symptoms. She suffered from rheumatic fever at the age of seven. Menstruation started at the age of twelve.

Physical examination revealed a thin, under-developed and slightly anæmic girl. She had no œdema, cyanosis, nor clubbing. Carotid pulsations were vigorous. The pulse rate was 120 a minute, regular and of water-hammer type. The blood pressure was $100 / 48$; temperature $102^{\circ} \mathrm{F}$. and respiration 26 a minute. The point of maximum cardiac impulse was localized at the right fifth intercostal space $1.25 \mathrm{~cm}$. external to the right midclavicular line. At this area the first sound was loud and an early diastolic and a mid-diastolic rumbling murmur were heard. A blowing early diastolic murmur was heard at both second intercostal spaces close to the sternum, being conducted along the right border of the sternum to the apex of the heart. The pulmonary second sound was accentuated. The gastric resonance was found on the right side. The remainder of the examination was normal. The patient was afebrile on the seventeenth day of illness and left the hospital after five weeks. 


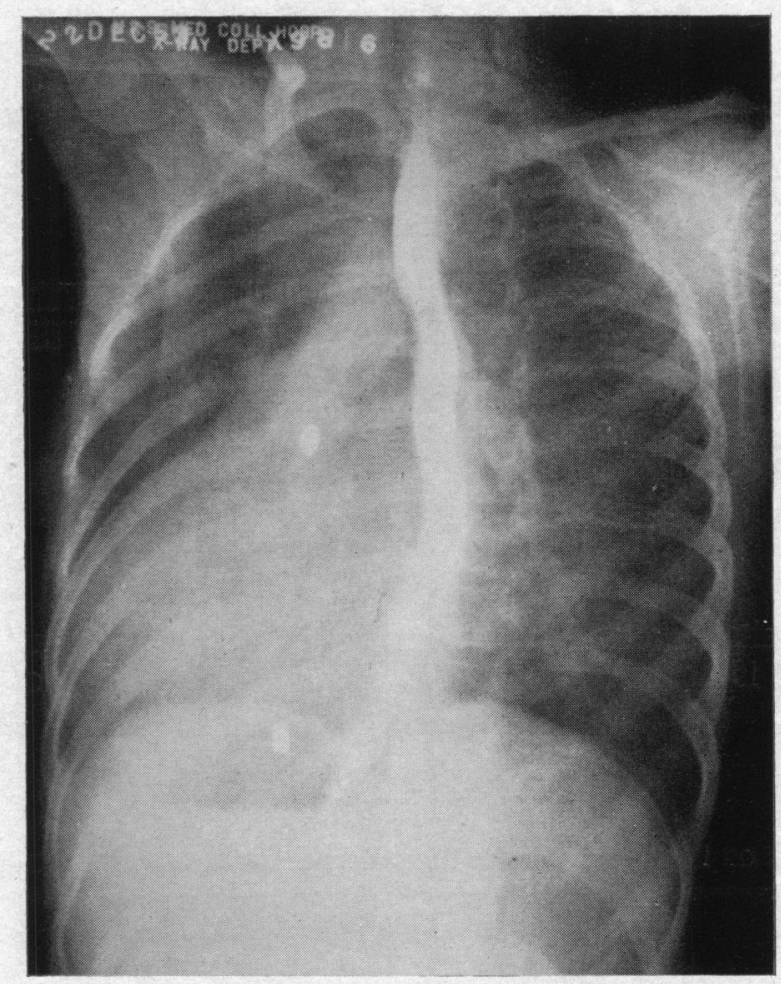

FIG. 1.-Teleradiogram of the heart in the left anterior oblique position, showing dextrocardia with situs inversus and enlargement of left auricle and left ventricle.

Investigations. Widal test was positive to TH in $1 / 125$ and to TO in $1 / 83$ on the ninth day of relapse of enteric fever. The Wassermann reaction of the blood was negative. X-rays of the heart showed dextrocardia with enlargement of left atrium and left ventricle (Fig. 1) and those of the skull absence of pneumatization of the frontal sinuses. Electrocardiograms showed the inversion of all the complexes in lead I and the interchanging of leads II and III cbaracteristic of dextrocardia, and left axis deviation.

\section{Summary}

A case of rheumatic mitral stenosis and aortic incompetence complicating dextrocardia with situs inversus in a fourteen-year-old girl is reported. The patient was admitted to the hospital for treatment of a relapse of enteric fever and the cardiac findings were incidental.

We are grateful to Dr. A. K. Dutta Gupta, Principal-cum-Superintendent, Nilratan Sircar Medical College and Hospitals for permission to report the case, and to Dr. B. Bhattacharya for drawing our attention to the case.

\section{References}

Abbott, A., and Russek, H. J. (1942). Amer. J. med. Sci., 204, 516.

Berkowitz, D., and Likoff, W. (1954). Ann. intern. Med., 40, 784.

Bleyer, J. M., and Saphir, W. (1953). Amer. Heart J., 46, 772.

Owen, S. A. (1911). Heart., 3, 113.

Panek, J. (1948). Casop. lék. česk., 87, 228.

Parson, G. W. (1945). Ann. intern. Med., 23, 102.

Pasternack, J. G. (1942). New England J. Med., 227, 953.

Pavel, S. (1933). Casop. lék. česk., 72, 301.

Silberstein, A. G., and Steinberg, S. (1943). New York State J. Med., 43, 1755. 